$\star \star \star$

$\star$ Polityli Europejskie,

$\star$ Finanse i Marketing

$\star \star \star \quad 17(66) 2017$

Zdzislaw Kochanowicz

Warszawska Wyższa Szkoła Ekonomiczna w Warszawie

Justyna Czaplicka

Akademia Pedagogiki Specjalnej w Warszawie

Piotr Bórawski

Uniwersytet Warmińsko-Mazurski w Olsztynie

\title{
Porównanie wybranych aspektów dzialań promocyjnych prowadzonych przez gminy wiejskie, miejsko-wiejskie i miejskie
}

\author{
COMPARISON OF SELECTED ASPECTS \\ OF PROMOTIONAL ACTIVITIES CONDUCTED \\ BY RURAL, URBAN-RURAL AND URBAN COMMUNITIES
}

\begin{abstract}
Celem badań było porównanie wybranych aspektów działań promocyjnych prowadzonych przez gminy miejsko-wiejskie $i$ miejskie oraz gminy wiejskie. W ramach celu głównego realizowano następujace cele szczegółowe: rozpoznanie działań promocyjnych stosowanych przez badane gminy, rozpoznanie form wspótpracy badanych z gminami partnerskimi, dokonanie oceny ważkości czynników decydujacych o atrakcyjności turystycznej gminy $w$ opinii badanych, dokonanie oceny ważkości barier $w$ rozwoju turystyki w badanej gminie. Grupę badawcza stanowiło 81 gmin z siedmiu województw Polski. Zastosowano metode sondażu diagnostycznego z wykorzystaniem techniki ankiety wedtug standaryzowanego kwestionariusza. Kwestionariusz ankiety wypetniaty osoby odpowiedzialne $w$ gminie za podejmowanie działań promocyjnych. Stwierdzono, ze między działaniami promocyjnym prowadzonymi przez gminy miejsko-wiejskie i miejskie oraz gminy wiejskie występuja różnice $w$ rodzaju stosowanych instrumentów oraz stopniu wykorzystywania poszczególnych działań. Ponadto badania wskazuja, iż gminy wiejskie rzadziej niż gminy miejskowiejskie nawiqzuja wspólprace z innymi podmiotami. Analiza odpowiedzi respondentów pokazała również ważność czynników świadczqcych o atrakcyjności turystycznej oraz bariery jakie moga utrudniać rozwój turystyki w gminach. Interesujacym obszarem do prowadzenia kolejnych badań jest poziom zidentyfikowania i promowania produktu turystycznego na poziomie lokalnym.
\end{abstract}

Key words: gmina, promocja, instrumenty promocyjne gminy

\section{Wstęp}

Rozwój jest najbardziej pożądanym procesem, kojarzony $\mathrm{z}$ pozytywnymi przeobrażeniami ilościowymi i jakościowymi. Rozwój lokalny określa się jako proces kształtowania zmian w kierunku jak najbardziej pożądanym, akceptowanym społecznie i ekonomicznie, zgodnie $\mathrm{z}$ wymogami racjonalnego gospodarowania przestrzenia, ochrony środowiska przyrodniczego i dziedzictwa kulturowego, w sposób kontrolowany, 
świadomy i celowy. Podstawową rolę w kształtowaniu tak rozumianego pojęcia powinien spełniać samorzą gminny (władze i administracja samorządowa) ${ }^{1}$.

Transformacja systemowa wprowadzając zasadnicze zmiany w układach zależności, przekształcając system podporządkowania wertykalnego w horyzontalny, zmieniła zakres obowiązków i funkcji pełnionych przez władze samorządowe. Gminy i powiat stały się ważnymi podmiotami zarządzania gospodarką lokalną, oczywiście w granicach określonych przez regulacje systemowe. W wielu dziedzinach, rynek jako mechanizm alokacji zasobów okazuje się być ułomny. W efekcie pojawia się konieczność stymulowania rozwoju przez władze samorządowe. O ile treścią rozwoju lokalnego są korzystne zmiany ilościowe i przemiany jakościowo-strukturalne oraz poprawa warunków życia ludności, nadrzędnym jego celem staje się zapewnienie dostatecznej liczby stabilnych miejsc pracy i dochodów $\mathrm{z}$ tytułu zatrudnienia, gwarantujących długoterminowe bezpieczeństwo finansowe i socjalne ludności, czyli de facto wzrost zamożności społeczeństwa².

Literatura podaje wiele sposobów wspierania rozwoju lokalnego, jednym z nich jest promocja gminy. Promocja zwana również polityką komunikacji lub polityką komunikowania organizacji $\mathrm{z}$ rynkiem, jest integralnym elementem strategii marketingowej organizacji. Promocja jest przedsięwzięciem gospodarczym i pociaga za sobą koszty, które akceptujemy oczekując efektów przekraczających wartość nakładów. Należy pamiętać, że promocja nie tworzy nowych możliwości tylko je pokazuje ${ }^{3}$.

Kreowanie pozytywnego wizerunku danego obszaru wymaga wprowadzenia efektywnej polityki promocji, w tym wyboru odpowiednich jej narzędzi. Obecnie prowadzenie długofalowych działań marketingowych częściej zauważalne jest w odniesieniu do dużych miast, województw czy krajów. Jednak polityka promocji powinna być także wdrażana $\mathrm{w}$ ujęciu lokalnym nie tylko w odniesieniu do mniejszych miast, ale także w kontekście gmin miejsko-wiejskich i wiejskich ${ }^{4}$.

Marketing terytorialny (ang. terytorial marketing) w literaturze naukowej znajdujemy definicję pojęcia jako "rynkową koncepcję zarządzania jednostką osadniczą - jako zarządzenie zmierzające do zaspokojenia potrzeb i pragnień mieszkańców. Niezbędne jest przy tym przewidywanie kierunku zmian oraz racjonalne wykorzystanie wszystkich posiadanych zasobów"5.

Philip Kotler i współautorzy przedstawiają marketing miejsc jako „zestaw działań mających na celu wzmocnienie pojemności wspólnot oraz regionów, tak aby mogły zaadoptować się do zmieniających się rynków poprzez realizowanie swoich szans na rozwój oraz podtrzymanie cech wartościowych (życiowych)"

\footnotetext{
${ }^{1}$ M. Ziółkowski M. Goleń: Zarządzanie strategiczne rozwojem lokalnym. [w:] Zarządzanie gospodarką i finansami gminy. SGGW, Warszawa 2006.

${ }^{2}$ E. Wojciechowski: Zarządzanie w samorządzie terytorialnym. DIFIN, Warszawa 2003.

${ }^{3}$ M. Florek, A. Augustyn: Strategia promocji jednostek samorządu terytorialnego - zasady i procedury, Fundacja Best Place - Europejski Instytut Marketingu Miejsc, Warszawa 2011.

4 K. Orfin: Polityka promocji jednostki samorządu terytorialnego w kreowaniu wizerunku obszarowego produktu turystycznego (na przykładzie gmin województwa zachodniopomorskiego). Rozprawy Naukowe Akademii Wychowania Fizycznego we Wrocławiu, Wrocław 2015.

${ }^{5}$ A. Szromnik: Marketing terytorialny. Miasto i region na rynku. Wolters Kluwer S. A., Warszawa 2016.

${ }^{6} \mathrm{Ph}$. Kotler, D. H. Haider, I. Rein : Marketing Places. Attracting investment, industry, and tourism to Cities, States and Nations. The free press, New York 1993.
} 
Natomiast Tadeusz Markowski przedstawia, iż „marketing terytorialny pojawił się jako kolejna próba przenoszenia $\mathrm{i}$ adaptacji koncepcji sprzedaży i zarządzania wypracowanych dla typowych produktów rynkowych konsumpcyjnych w sektorze prywatnym do sektora publicznego[...]jest to wyjście naprzeciw potrzebie profesjonalizacji zarządzania jednostkami terytorialnymi"’ .

Ograny administracji publicznej, chcąc sprostać wciąż rosnącym wymaganiom społeczeństwa, muszą włączyć w procesy „tradycyjnego” administrowania nowe, proaktywne i profesjonalne formy i modele zarządzania które dotąd były właściwe organizacjom sektora prywatnego. Obszarem działań administracji publicznej w których można zastosować te rozwiązania (zwłaszcza narzędzia marketingowe) jest płaszczyzna informacyjno-promocyjna ${ }^{8}$.

Promocja jako jeden $\mathrm{z}$ instrumentów komunikacji marketingowej funkcjonująca obok produktu, ceny i dystrybucji jest pojęciem o węższym znaczeniu niż komunikacja marketingowa. Jest to działalność informująco-nakłaniająca, tworząca pozytywny wizerunek marki i oferenta, którym może być instytucja publiczna?

Za pomocą polityki promocji $\mathrm{i}$ jej instrumentów możliwa jest komunikacja samorządu terytorialnego ze społecznością lokalną, prezentacja wybranych elementów tożsamości, przekazywanie środowisku różnorodnych informacji społecznoekonomicznych, ekspozycja atutów i atrakcji, osiagnięć czy zamierzeń ${ }^{10}$.

Do instrumentów promocji-mix można zaliczyć: reklamę, promocję sprzedaży, public relations, sprzedaż osobistą, marketing bezpośredni. Odpowiednio dobrana kompozycja instrumentarium $\mathrm{w}$ kontekście polityki promocji może mieć bezpośredni wpływ na planowany sposób postrzegania obszarowego produktu turystycznego wewnątrz JST, jak też poza nią ${ }^{11}$.

W badaniach przeprowadzonych w 2013 roku przez Europejski Instytut Marketingu Miejsc określono czynniki sukcesu i bariery promocji JST. Jeśli chodzi o elementy, które determinuja sukces $\mathrm{w}$ promocji to respondenci wykazali się pragmatyzmem i wskazali na pierwszym miejscu grupę czynników wdrożeniowych, związanych przede wszystkim $\mathrm{z}$ konsekwencją $\mathrm{w}$ realizacji opracowanego planu działania/strategii promocji. Na drugim miejscu wymienione zostały czynniki bezpośrednio związane $\mathrm{z}$ operacyjną działalnością promocyjną (narzędziowe), które sprowadzają się praktycznie do jednego - właściwego dobrania zasięgu terytorialnego oraz narzędzi promocyjnych do celów i oczekiwań grup docelowych działań. Na kolejnych miejscach znalazły się następujące grupy czynników: zasoby, czynniki finansowe, czynniki wizerunkowe, czynniki kreatywne, czynniki strategiczne.

\footnotetext{
${ }^{7}$ T. Markowski: Zarządzanie rozwojem miast. Wydawnictwo Naukowe PWN, Warszawa 1999.

${ }^{8}$ J. Osiński: Administracja publiczna a gospodarka regionalna i lokalna [w:] Gospodarka regionalna i lokalna, red. Z. Strzelecki, Warszawa 2008

${ }^{9}$ B. Szymoniuk: Komunikacja marketingowa. Instrumenty i metody. Polskie Wydawnictwo Ekonomiczne SA, Warszawa 2006.

${ }^{10}$ T. Domański: Skuteczna promocja miasta i regionu podstawowym zadaniem marketing terytorialnego, [w:] Markowski T. (red.), Marketing terytorialny. PAN, Komitet Przestrzennego Zagospodarowania Kraju, Studia, CXVI, Warszawa 2006.

${ }^{11}$ W. Żurawik: Marketing. Podstawy i kontrowersje, Uniwersytet Gdański, Gdańsk 2005.

J. Wiktor: Komunikacja marketingowa. Modele, struktury, formy przekazu. WN PWN, Warszawa 2013.
} 
Ankietowani poproszeni o wskazanie najbardziej efektywnych ich zdaniem narzędzi promocji JST wymieniali przede wszystkim: reklamę w TV oraz w Internecie, PR, event marketing oraz działania $w$ serwisach społecznościowych. Zdecydowana większość respondentów (77\%) uważa, że środki przeznaczone na działania promocyjne $\mathrm{w}$ ich JST nie są adekwatne do potrzeb promocyjnych ${ }^{12}$.

\section{Działania promocyjne gmin}

W wyniku rywalizacji o inwestorów, turystów, zasoby gmin i regionów, ośrodki dążą do zwiększenia swojej konkurencyjności ${ }^{13}$.

W literaturze sklasyfikowano produkty jednostek samorządu terytorialnego na następujące elementy:

- $\quad$ zasadnicze (nuclear) - obejmują miasto/gmine jako całość składającą się ze struktury fizycznej, funkcji, działalności, atmosfery oraz symbolicznych wartości zawartych w nazwie miasta/gminy z nią związanych i kojarzonych;

- wspomagające (contributory) - obejmują specyficzne usługi, udogodnienia czy wartości dostępne właśnie w tym miejscu ${ }^{14}$.

Istotną rolę w stymulowaniu rozwoju danej jednostki terytorialnej odgrywają władze lokalne, których głównym zadaniem jest zaspokajanie zbiorowych potrzeb społeczności lokalnych i inicjowanie działań, które będą zmierzały właśnie w tym kierunku.

Podobnie literatura przedmiotu określa czynniki definiujące produkt gminy. Odbiorcami produktu gminy są mieszkańcy gminy, podmioty gospodarcze zlokalizowane na terenie gminy, i gmin sąsiednich. $Z$ punktu widzenia realizacji planowanych działań i osiągnięcia założonych celów, można wyróżnić inne ważne grupy docelowe ${ }^{15}$.

Marian Huczek wymienia najważniejsze działania promocyjne gmin:

1. Stworzenie pozytywnego wizerunku gminy. Dobry wizerunek gminy jest bardzo ważny w ubieganiu się o inwestorów turystów czy środki pomocowe. Wizerunek ten możemy osiągnąć poprzez:

— obecność w mediach - konferencje prasowe;

— przyjazny stosunek do przybyszów (tablice i znaki informacyjne);

- upublicznianie i podkreślanie indywidualnego wizerunku gminy (tradycje obyczaje);

- opracowanie i realizacja kalendarza działań promocyjnych.

2. Rozpowszechnianie oferty, informacji o możliwościach. Informacja o ofercie powinna być spójna ze strategią promocji, dopracowana tak żeby w jak

\footnotetext{
12 A. Mikołajczyk, M. Florek, J. Górski, M. Jankowska: TOP PROMOCJI polskich miast, powiatów i regionów 2013, Raport z badania przeprowadzonego przez Best Place - Europejski Instytut Marketingu Miejsc, Warszawa 2013.

${ }^{13}$ G. Candela, P. Figini: The Economics of Tourism Destinations. Springer, Bologna, 2010.

${ }^{14}$ W. Wrzoska: Strategie marketingowe, Polskie Wydawnictwo Ekonomiczne, Warszawa 2004.

${ }^{15}$ E. Glińska, T. Popławski: Promocja miasta jako instrument marketingu terytorialnego,[w:] Michałowski K. (red.), Informacja i promocja w turystyce, Materiały konferencyjne z I Sympozjum Naukowego „Znaczenie informacji i promocji w gospodarce turystycznej”, Politechnika Białostocka, Białystok, 2002.
} 
najmniejszej ilości słów niosła jak najwięcej informacji. Informacja rozprzestrzeniana jest poprzez działania reklamowe:

— strony internetowe;

- bazy danych, katalogi, katalogi branżowe;

- promocja bezpośrednia - udział w konferencjach tematycznych, targach;

- bilbordy i tablice informacyjne;

— informacje o polityce rozwoju i jej narzędziach;

- funkcjonowanie stanowisk do spraw promocji;

- funkcjonowanie punktów informacyjnych w urzędach;

- lokalne pisma.

3. Zainwestowanie $\mathrm{w}$ poprawę swojej pozycji konkurencyjnej. Działania podnoszące wartość i atrakcyjność terenów oraz pozwalające na skrócenie czasu realizacji inwestycji. Służą temu:

— programy podnoszace kwalifikacje na rynku pracy;

- poprawa infrastruktury;

- przygotowania planistyczne i prawne, uzgodnienia warunków podłączenia do infrastruktury terenów których rozwój chcemy promować.

4. Stosowanie zachęt. Istnieje długa lista zachęt i różnych niekonwencjonalnych rozwiązań które stosujemy dla przyciągnięcia wybranych partnerów gospodarczych, są wśród nich:

— niskie ceny terenów i budynków;

— niskie opłaty dzierżawne;

— strefy przemysłowe i specjalne strefy ekonomiczne;

- oferty towarzyszące (programy mieszkaniowe, programy adaptacji społecznej).

5. Mobilizowanie dynamiki gospodarczej. Celem jest zmiana niekorzystnej opinii o danym terenie. Do działań w tym zakresie należą:

— pobudzanie aktywności mieszkańców i przedsiębiorców z terenów, które chcemy rozwinąc;

— reklama oferty;

- targi, wystawy, giełdy przyciagające potencjalnych partnerów;

- przetargi, konkursy na zagospodarowanie czy kupno nieruchomości, prowadzenie przedsiębiorstw komunalnych $\mathrm{i}$ inne przedsięwzięcia pożądane dla rozwoju;

- podejmowanie inicjatyw w zakresie profesjonalnej i kompleksowej obsługi turystów oraz działan zmierzających do rozwoju infrastruktury i bazy turystycznej.

6. Wykorzystanie możliwości, Podchwytywanie zainteresowania, negocjowanie porozumienia, stanie się to możliwe dzięki dostosowania organizacji w gminie do warunków szybkich, dynamicznych negocjacji:

- zmiana nastawienia do potencjalnego partnera;

- centra obsługi inwestora.

7. Promocja międzynarodowa. Do przedsięwzięć podejmowanych w międzynarodowych kampaniach promocyjnych należą głównie: 
- zamieszczanie ofert i informacji w katalogach o zasięgu międzynarodowym;

— interaktywne bazy danych;

- biuletyny biur radcy handlowego i attache handlowych ambasad;

- zagraniczne targi i wystawy;

- wystawy międzynarodowe w Polsce;

— współpraca z miastami i gminami partnerskimi ${ }^{16}$.

\section{Cel i metoda badań}

Głównym celem badań było poznanie i porównanie wybranych aspektów działań promocyjnych prowadzonych przez gminy miejsko-wiejskie, miejskie i gminy wiejskie. W ramach celu głównego realizowano następujące cele szczegółowe:

- rozpoznanie działań promocyjnych stosowanych przez badane gminy,

- rozpoznanie form współpracy badanych z gminami partnerskimi,

- dokonanie oceny ważkości czynników decydujących o atrakcyjności turystycznej gminy w opinii badanych,

— dokonanie oceny ważkości barier w rozwoju turystyki w badanej gminie.

Założono, że osiagnnięcie powyższego celu badawczego mogło mieć miejsce tylko przy uzyskaniu odpowiedzi na następujące pytania badawcze:

- Jakie działania są podejmowane w gminie na rzecz promocji?

- W jakich formach badane gminy nawiązują współpracę z gminami partnerskimi?

- Jakie czynniki zdaniem badanych wpływają na atrakcyjność turystyczną gminy?

- Jakie czynniki zdaniem badanych stwarzają bariery w rozwoju turystyki w gminie?

W celu przeprowadzenia badań zastosowano metodę sondażu diagnostycznego $\mathrm{z}$ wykorzystaniem techniki ankiety według standaryzowanego kwestionariusza. W procesie analizy danych wykorzystano metody graficzne i opisowe.

Przedmiotem zaprojektowanych badań były działania promocyjne podejmowane przez gminy. Podmiotem badania była grupa 81 gmin siedmiu województw Polski (gminy z województw mazowieckiego, podlaskiego, warmińsko-mazurskiego, kujawskopomorskiego, pomorskiego, łódzkiego, wielkopolskiego). Kwestionariusz ankiety wypełniały osoby odpowiedzialne za prowadzenie działań promocyjnych w gminie. Zastosowano dobór celowy, a jego najważniejszą funkcją było wyrażenia przez pracownika gminy chęci wzięcia udziału w badaniu. Badanie przeprowadzone było w okresie od 01 października 2016 r. do 19 stycznia 2017 r.

\section{Wyniki badań}

W badaniu wzięło udział 81 pracowników gmin, zajmujących się w swojej jednostce działaniami promocyjnymi. Gminy rozlokowane były na terenie siedmiu województw

\footnotetext{
${ }^{16}$ M. Huczek: Promocja gminy jako sposób wspierania lokalnego rozwoju społeczno-gospodarczego. Zeszyty Naukowe Wyższej Szkoły Humanitas nr 1/2007.
} 
Polski, gminy z województw: mazowieckiego, podlaskiego, warmińsko-mazurskiego, kujawsko-pomorskiego, pomorskiego, łódzkiego, wielkopolskiego. W badaniem objęto 66 gmin wiejskich, 2 miejskie oraz 13 wiejsko-miejskich, dla dokonania analizy porównawczej gminy miejskie i wiejsko-miejskie włączono do jednej kategorii.

W wyniku przeprowadzonych badań stwierdzono, że gminy miejsko-wiejskie i miejskie częściej niż gminy wiejskie stosują takie działania jak: prowadzenie strony www, organizacja imprez okolicznościowych, wydawanie lokalnej gazety, folderu, współpraca z organizacjami turystycznymi, programy w lokalnej telewizji. Największa rozbieżność w wykorzystywaniu danych narzędzi promocji, występuję w kategorii współpraca z organizacjami turystycznymi. Współpraca taka nawiązywana jest w $67 \%$ przez gminy miejsko-wiejskiej i miejskie, natomiast w przypadku badanych gmin wiejskich badani nawiązali taką współpracę w 18\%. Fakt takiego zróżnicowania może mieć związek z lokalizacją organizacji turystycznych na terenie miast.

Gminy wiejskie stosują natomiast dodatkowe działania promocyjne nie ujęte w kwestionariuszu, tj.: współpraca $\mathrm{z}$ organizacją „Zaścianek Mazowsza”, artykuły $\mathrm{w}$ prasie, publikacje promocyjne $\mathrm{w}$ prasie regionalnej, publikacje promocyjne na portalach internetowych, materiały $\mathrm{w}$ lokalnym radiu. Natomiast dodatkowym, nie wymienianym przez przedstawicieli gmin wiejskich działaniem promocyjnym stosowanym w przypadku gmin miejsko-wiejskich i miejskich jest prowadzenie portalu społecznościowego (wyk. 1).

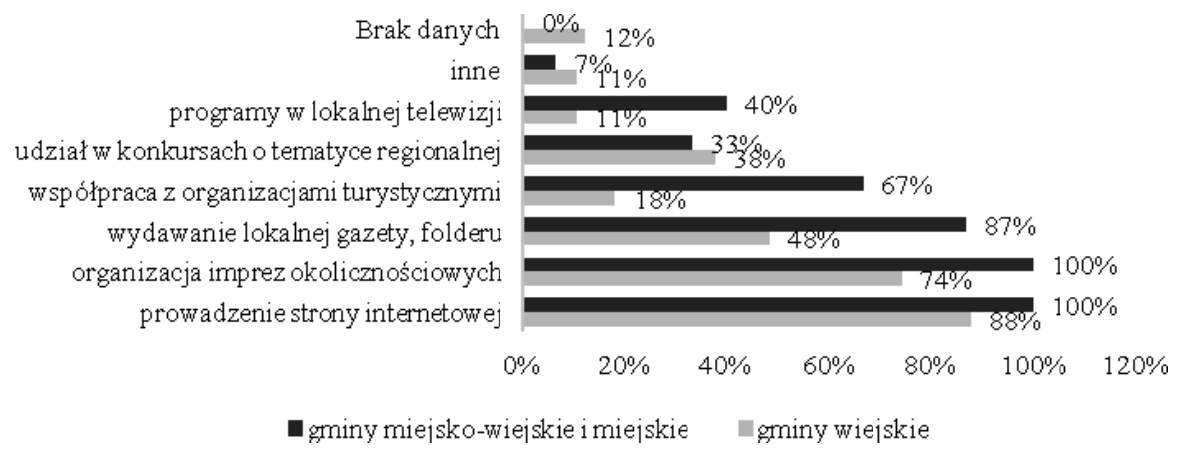

Wykres 1. Działania podejmowane w gminach na rzecz promocji

Źródło: opracowanie własne na podstawie przeprowadzonych badań.

Uzyskane wyniki znajduja potwierdzenie $\mathrm{w}$ badaniach przeprowadzonych przez Matysik-Pejas R., Wojewodzic T. Autorzy w swojej publikacji pt. Rola kanałów przepływu informacji w marketingu terytorialnym wskazuja jednoznacznie na bardzo duże większego zaangażowania samorządu $w$ redagowanie atrakcyjnych stron internetowych oraz docenienie znaczenia prasy lokalnej. Autorzy opracowania podkreślają również znaczenie informacji przekazywanej w sposób niesformalizowany oraz występowania w strukturze urzędu gminy komórek odpowiedzialnych za transfer informacji (biuro obsługi klienta, biuro promocji) ${ }^{17}$.

\begin{tabular}{llcccc}
\hline $17 \quad$ R. Matysik-Pejas, & T. Wojewodzic: $\quad$ Rola kanałów przepływu informacji \\
w marketingu terytorialnym, Acta Scientiarum Polonorum. Oeconomia, $8(3), 2009$. &
\end{tabular} 
Należy podkreślić, że we wszystkich gminach, od których otrzymano dane prowadzona jest strona www i traktowana jest przez respondentów jako działanie promocyjne. Często stosowanym działaniem promocyjnym jest także organizowanie imprez okolicznościowych i wydawanie lokalnej gazety.

Nie wszystkie instrumenty promocji są tworzone i finansowane przez gminy w sposób autonomiczny. Praktyka działalności samorządowej uwidacznia, że obok instrumentów stosowanych samodzielnie występuje pokaźny zespół instrumentów budowanych i stosowanych przy współudziale podmiotów gospodarczych, instytucji wspierania biznesu, organów administracji centralnej, organizacji społecznych oraz innych gmin.

Takie wspólne przedsięwzięcia, łączące zasoby finansowe, kadrowe oraz zasoby wiedzy pozwalają odciążyć budżet gminy oraz kadrę urzędu gminy, a także niejednokrotnie uzyskać efekty synergiczne i mnożnikowe. Często są jedyną osiagalną metodą kreacji danego instrumentu.

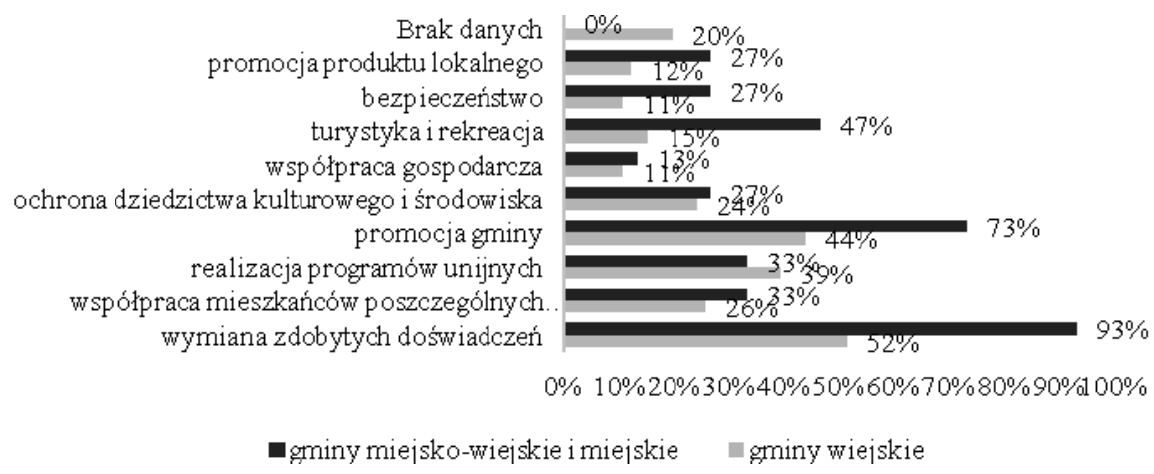

Wykres 2. Formy współpracy z gminami partnerskimi

Źródło: opracowanie własne na podstawie przeprowadzonych badań.

Przeprowadzone badania wskazują iż gminy miejsko-wiejskie i miejskie podejmują współpracę z innymi podmiotami częściej niż gminy wiejskie w każdej z podawanych kategorii oprócz wspólnej realizacji programów unijnych (wyk. 2). Gminy miejskowiejskie i miejskie najczęściej podejmują współpracę w obszarze: wymiana zdobytych doświadczeń, promocja gminy oraz turystyka i rekreacja. Gminy wiejskie natomiast w obszarze: wymiana zdobytych doświadczeń, promocja gminy oraz realizacja programów unijnych. Może mieć to związek z wyższą efektywnością projektu partnerskiego oraz wymagań co do minimalnych wskaźników i wartości projektów - mniejsze gminy wiejskie zawiązują partnerstwa, aby sprostać wymaganiom konkursów rozdysponowujących środki unijne.

Warto również zwrócić uwagę na największe rozbieżności między okolicznościami zawiązywania współpracy gminy miejsko-wiejskich i miejskich oraz gmin wiejskich. I tak, największa różnica $\mathrm{w}$ odpowiedziach występuje w obszarze wymiana zdobytych 
doświadczeń, następnie promocja gminy oraz turystyka i rekreacja. Wynika to $\mathrm{z}$ wysokiej aktywności w tych obszarach gmin miejsko-wiejskich i miejskich.

Ciekawy jest również fakt nie udzielenia odpowiedzi na to pytanie przez $20 \%$ ankietowanych przedstawicieli gmin wiejskich, może to wskazywać na brak nawiązywania jakiejkolwiek współpracy. Fakt ten może wskazywać na deficyt wiedzy na temat korzyści wynikających $\mathrm{z}$ nawiązywania partnerstw i kooperacji oraz możliwości ich nawiązywania wśród części gmin wiejskich.

Jednostki samorządu terytorialnego prowadzonymi działaniami promocyjnymi kreują pozytywny obraz swojej gminy, zachęcają do inwestowania, osiedlania, zwiedzania. Celem prowadzonych przez gminy działań promocyjnych jest więc zarówno informowanie, jak i przekonywanie o atrakcyjności i korzyściach płynących $\mathrm{z}$ nabycia, a następnie używania produktu. Dlatego też, w prowadzonych badaniach ujęto pytania dotyczące oceny czynników świadczących o atrakcyjności badanego obszaru oraz pytania dotyczące oceny czynników stanowiących barierę w rozwoju turystyki na danym terenie.

Rozwój turystyki na terenie danego terytorium jest wielokrotnie powtarzającym się celem strategii rozwoju gmin, miast i powiatów w Polsce. Aby skutecznie realizować ten cel jednostki samorządu terytorialnego realizują działania na rzecz tego celu we wszystkich dziedzinach, w tym także w promocji. Dany obszar jest szczególnie zdeterminowanym geograficznie produktem turystycznym, definiowanym jako zbiór wybranych elementów potencjału turystycznego danego obszaru, które połączone są nadrzędną ideą. Decydują one o jego oryginalności, atrakcyjności i odrębności ${ }^{18}$. Podstawowym elementem produktu turystycznego obszaru jest jego dziedzictwo, do którego zalicza się elementy powstałe w wyniku naturalnych procesów przyrodniczych i działalności człowieka, m.in. rzeki, jeziora, budynki, wydarzenia kulturalne ${ }^{19}$.

\footnotetext{
${ }^{18}$ A. Kornak, A. Rapacz: Zarządzanie turystyką i jej podmiotami w miejscowości i regionie, AE, Wrocław 2001.

${ }^{19}$ D. J. Timothy, S. W. Boyd: Heritage tourism. Pearson Education Limited, New York 2003.
} 


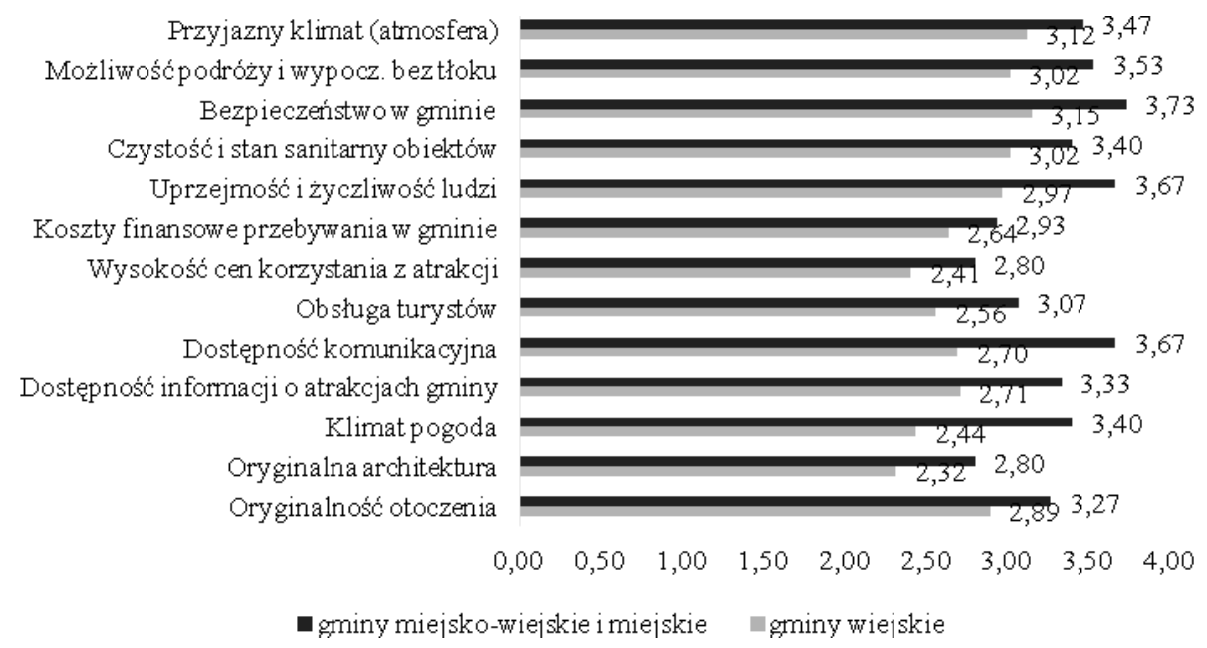

Wykres 3. Atrakcyjność turystyczna gminy w opinii badanych

*Atrakcyjność oceniono w skali 1-5, gdzie 5 oznacza czynnik decydujący, 4 - czynnik bardzo korzystny, 3 - czynnik korzystny, 2 - czynnik obojętny, 1 - czynnik nieważny.

Źródło: opracowanie własne na podstawie przeprowadzonych badań.

Obszary wiejskie w Polsce skupiają znaczące zasoby turystyczne: przyrodnicze i kulturowe oraz wyróżniają się dużym potencjałem do uprawiania aktywnych form rekreacji w naturalnym krajobrazie. Naturalnym wydaje się, że jednym z wskazywanych i planowanych kierunków rozwoju gmin wiejskich w Polsce jest turystyka.

Z przeprowadzonych badaniach wynika, że ważność wszystkich czynników jest wyższa w opinii respondentów $\mathrm{z}$ gmin miejsko-wiejskich i miejskich niż w opinii respondentów $\mathrm{z}$ gmin wiejskich. Za najistotniejszy $\mathrm{w}$ opinii przedstawicieli gmin miejsko-wiejskich i miejskich uznano: bezpieczeństwo w gminie, uprzejmość i życzliwość ludzi oraz dostępność komunikacyjną. Natomiast w opinii przedstawicieli gmin wiejskich za najważniejsze uznano: bezpieczeństwo w gminie, przyjazny klimat (atmosfera), możliwość podróży i wypoczynku bez tłoku, czystość i stan sanitarny obiektów (wyk. 3).

Analizując natomiast odpowiedzi dotyczących bariery rozwoju turystyki w gminie respondenci reprezentujący gminy miejsko-wiejskie i miejskie wskazali: niskie dochody obiektów turystycznych, słaby produkt turystyczny oraz niekorzystny klimat. Przedstawiciele gmin wiejskich bariery rozwoju turystyki również dostrzegali w niskich dochodach obiektów turystycznych oraz słabym produkcie turystycznym, jednak największą przeszkodą w ich ocenie jest brak dostępu do atrakcji (wyk. 4). 


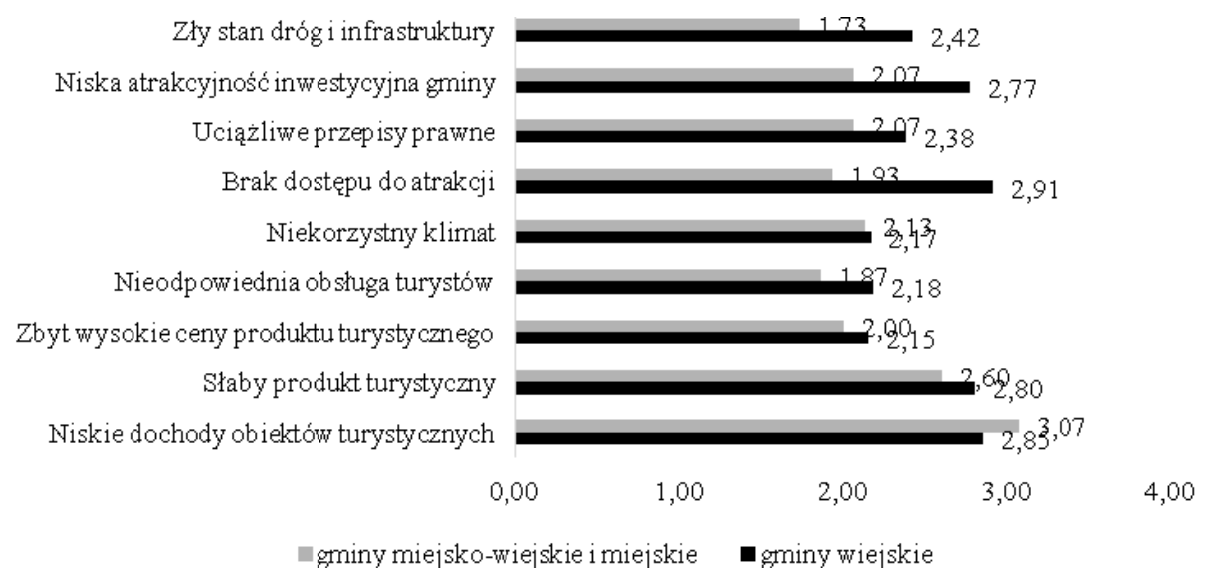

Wykres 4. Bariery rozwoju turystyki w gminie w opinii badanych *Bariery oceniono w skali 1-5, gdzie 5 oznacza czynnik decydujący, 4 - czynnik bardzo korzystny, 3 - czynnik korzystny, 2 - czynnik obojętny, 1 - czynnik nieważny. Źródło: opracowanie własne na podstawie przeprowadzonych badań.

Z przeprowadzonych badań wynika, że wiele gmin zarówno miejsko-wiejskich, miejskich jak i gmin wiejskich, nie posiada dobrze zidentyfikowanego produktu turystycznego, który jest przez gminy promowany i wspierany. Dobrze opracowana, długofalowa polityka promocji zidentyfikowanego produktu turystycznego mogłaby przynieś rozwój turystyki na szczeblu lokalnym

\section{Podsumowanie i wnioski}

Współczesne procesy konkurencji o klienta, inwestora, turystę wymagają od jednostek samorządu terytorialnego kreowania interesującego wizerunku produktu turystycznego. Prowadzenie polityki promocji przez JST powinno mieć charakter długookresowy, powinna mu towarzyszyć świadomość korzyści wynikających z tej polityki. Wobec wzrastającej roli, jaką w życiu społecznym i gospodarczym odgrywa informacja, istnieje potrzeba dostosowania jej struktury i kanałów dystrybucji do potrzeb odbiorcy i nadawcy informacji. Jak wynika z przeprowadzonych badań gminy miejsko-wiejskie i miejskie częściej niż gminy wiejskie stosują zróżnicowane działania promocyjne.

Analiza zebranego materiału badawczego wskazuje, że gminy miejsko-wiejskie i miejskie podejmują współpracę z innymi podmiotami częściej niż gminy wiejskie w każdej z ujętej w kwestionariuszu kategorii oprócz wspólnej realizacji programów unijnych. Warto również zwrócić uwagę na fakt nie udzielenia odpowiedzi na to pytanie przez $20 \%$ ankietowanych przedstawicieli gmin wiejskich, co może wskazywać na brak nawiązywania jakiejkolwiek współpracy przez te jednostki.

Z przeprowadzonych badaniach wynika, że za najistotniejszy czynnik wpływający na atrakcyjność gminy w opinii przedstawicieli gmin miejsko-wiejskich i miejskich uznano: bezpieczeństwo w gminie, uprzejmość i życzliwość ludzi oraz dostępność komunikacyjną. Natomiast w opinii przedstawicieli gmin wiejskich za najważniejsze 
uznano: bezpieczeństwo w gminie, przyjazny klimat (atmosfera), możliwość podróży i wypoczynku bez tłoku, czystość i stan sanitarny obiektów.

Analizując odpowiedzi dotyczące barier rozwoju turystyki w gminie respondenci reprezentujący gminy miejsko-wiejskie i miejskie wskazali: niskie dochody obiektów turystycznych, słaby produkt turystyczny oraz niekorzystny klimat. Przedstawiciele gmin wiejskich bariery rozwoju turystyki również dostrzegali w niskich dochodach obiektów turystycznych oraz słabym produkcie turystycznym, jednak największą przeszkodą w ich ocenie jest brak dostępu do atrakcji.

\section{Bibliografia}

Candela G., Figini P.: The Economics of Tourism Destinations, Springer, Bologna, 2010.

Domański T.: Skuteczna promocja miasta i regionu podstawowym zadaniem marketing terytorialnego, [w:] Markowski T. (red.), Marketing terytorialny, PAN, Komitet Przestrzennego Zagospodarowania Kraju, Studia, CXVI, Warszawa 2006.

Florek M., Augustyn A.: Strategia promocji jednostek samorządu terytorialnego - zasady i procedury, Fundacja Best Place - Europejski Instytut Marketingu Miejsc, Warszawa 2011.Glińska E., Popławski T.: Promocja miasta jako instrument marketingu terytorialnego,[w:] Michałowski K. (red.), Informacja i promocja w turystyce, Materiały konferencyjne z I Sympozjum Naukowego „Znaczenie informacji i promocji w gospodarce turystycznej”, Politechnika Białostocka, Białystok, 2002.

Huczek M.: Promocja gminy jako sposób wspierania lokalnego rozwoju społeczno-gospodarczego, Zeszyty Naukowe Wyższej Szkoły Humanitas nr 1/2007.

Kornak A., Rapacz A.: Zarządzanie turystyką i jej podmiotami w miejscowości i regionie, AE, Wrocław 2001. Kotler P., Haider D.H., Rein I.: Marketing Places. Attracting investment, industry, and tourism to Cities, States and Nations, The free press, New York 1993.

Markowski T.: Zarządzanie rozwojem miast, Wydawnictwo Naukowe PWN, Warszawa 1999.

Matysik-Pejas R., Wojewodzic T.: Rola kanałów przepływu informacji w marketingu terytorialnym, Acta Scientiarum Polonorum. Oeconomia, 8(3), 2009.

Mikołajczyk A., Florek M., Górski J., Jankowska M.: TOP PROMOCJI polskich miast, powiatów i regionów 2013, Raport z badania przeprowadzonego przez Best Place - Europejski Instytut Marketingu Miejsc, Warszawa 2013.

Orfin K.: Polityka promocji jednostki samorządu terytorialnego w kreowaniu wizerunku obszarowego produktu turystycznego (na przykładzie gmin województwa zachodniopomorskiego), Rozprawy Naukowe Akademii Wychowania Fizycznego we Wrocławiu, Wrocław 2015.

Osiński J.: Administracja publiczna a gospodarka regionalna i lokalna [w:] Gospodarka regionalna i lokalna, red. Z. Strzelecki, Warszawa 2008.

Szromnik A.: Marketing terytorialny. Miasto i region na rynku, Wolters Kluwer S. A., Warszawa 2016.

Szymoniuk B.: Komunikacja marketingowa. Instrumenty i metody, Polskie Wydawnictwo Ekonomiczne SA, Warszawa 2006.

Timothy D.J., Boyd S.W.: Heritage tourism, Pearson Education Limited, New York 2003.

Wiktor J.: Komunikacja marketingowa. Modele, struktury, formy przekazu, WN PWN, Warszawa 2013.

Wojciechowski E.: Zarządzanie w samorządzie terytorialnym, DIFIN, Warszawa 2003.

Wrzoska W.: Strategie marketingowe, Polskie Wydawnictwo Ekonomiczne, Warszawa 2004.

Ziółkowski M., Goleń M.: Zarządzanie strategiczne rozwojem lokalnym. [w:] Zarządzanie gospodarką i finansami gminy, SGGW, Warszawa 2006.

Żurawik W.: Marketing. Podstawy i kontrowersje, Uniwersytet Gdański, Gdańsk 2005.

\section{Summary}

The aim of the study was to recognize and compare selected aspects of promotion activities conducted by urban-rural, urban communities, and rural communities. Within the framework of the main objective the following specific objectives were fulfilled: recognition of promotional measures applied by the examined communities, recognition of the forms of cooperation between communities, assessment of the importance of factors determining the tourist 
attractiveness of the community in the opinion of the respondents, and evaluation of the importance of barriers in the development of tourism in the studied municipality. The research group was comprised of 81 municipalities from seven Polish voivodeships. The diagnostic applied was a method using a survey technique according to a standardized questionnaire. The survey questionnaire was filled by responsible persons within the municipality, for undertaking promotional activities. It has been found that there are differences in the type of instruments used, and the extent to which individual activities are used, between promotional activities carried out by urban-rural, urban communities, and rural communities. In addition, research indicates that rural communities are less likely than urban / rural municipalities to offer cooperation with other entities. The analysis of respondents' responses also showed the importance of the supporting factors in the attractiveness of tourism and the barriers that may hinder the development of tourism in municipalities. The level of identification and promotion of a tourist product at the local level is an interesting area for further research.

Key words: community, promotion, commune promotional instruments.

Informacja o autorach:

mgr Zdzisław Kochanowicz

Warszawska Wyższa Szkoła Ekonomiczna w Warszawie

mgr Justyna Czaplicka

Akademia Pedagogiki Specjalnej w Warszawie

dr hab. Piotr Bórawski,

Uniwersytet Warmińsko-Mazurski w Olsztynie, Katedra Agrotechnologii Zarządzania Produkcja

Rolniczą i Agrobiznesu,

Plac Łódzki 2, 10-957 Olsztyn

e-mail: pboraw@uwm.edu.pl 